\title{
ИСКОПАЕМЫЕ МИКРООРГАНИЗМЫ И СЛЕДЫ ИХ ЖИЗНЕДЕЯТЕЛЬНОСТИ В БОКСИТАХ КМА
}

\author{
М. Ю. Овчинникова ${ }^{1}$ Е. А. Жегалло ${ }^{2}$ \\ ${ }^{1}$ Воронежский государственный университет \\ ${ }^{2}$ Палеонтологический институт им. А. А. Борисяка РАН, г. Москва
}

Поступила в редакцию 6 апреля 2019 г.

\begin{abstract}
Аннотация: статья включает материаль изучения бокситов Курской магнитной аномалии (КМА) с помощью сканирующего электронного микроскопа (СЭМ). В результате обнаружень многочисленные микроорганизмы (фрагменты нитчатых и коккоидных бактерий, трихомов циианобактерий, гифов микрогрибов) и продукты их жизнедеятельности (гликокаликс и биопленки). Микроорганизмы выполняли деструктивную функиию, выраженную в разрушении минералов материнских пород, а также выступали в роли накопителя бокситового вещества.
\end{abstract}

Ключевые слова: бокситы, биоморфозы, КМА, кора выветривания

\section{FOSSIL MICROORGANISMS AND TRACKS OF THEIR LIFE IN KMA BOXYTES}

\begin{abstract}
Kursk Magnetic Anomaly (KMA) using a scanning electron microscope (SEM). As a result we found numerous microorganisms (fragments of filamentous and coccoid bacteria, trichomes of cyanobacteria, hyphae of micro fungi) and their metabolic products (glycocalyx and biofilms). Microorganisms performed a destructive function, expressed in the destruction of the minerals of the parent rocks, and also acted as an accumulator of bauxite substance.
\end{abstract}

Key words: bauxite, biomorphosis, KMA, weathering crust

\section{Введение}

Бокситы являются основным сырьем при производстве алюминия. Они содержат как собственно минералы алюминия, железа и кремния, так и их ассоциации. Возникновение бокситовых залежей происходит в эпохи континентальных перерывов при благоприятных для интенсивного выветривания климатических и тектонических обстановках в условиях мощнейшего воздействия органического мира.

Еще в середине прошлого века $[1,2]$ были высказаны предположения об участии в формировании бокситов биологических образований, но большинство исследователей рассматривали этот процесс как чисто химический и недооценивали роль микроорганизмов в процессах выветривания.

Проблема взаимодействия микроорганизмов с минералами и породами важна в связи с изучением биогеохимических процессов выветривания и миграции элементов. Микроорганизмы активно воздействуют на все без исключения минералы, они являются неотъемлемой частью процессов выветривания и проделывают огромную работу в образовании латеритов и формировании месторождений полезных ископаемых с ними связанных.
Уже в первых работах по изучению бокситов с помощью СЭМ были зафиксированы формы, представленные псевдоморфозами гиббсита и бемита по бактериям, грибам, обнаруженные в бокситах Индии, Бразилии, Гвинеи и Урала [3-7]. Минерализованные остатки биогенных форм были обнаружены в месторождениях бокситов как латеритных, так и переотложенных. В этой связи представляется перспективным изучение бокситов КМА методом сканирующей электронной микроскопии.

Толща бокситов КМА локализуется в позднетурнейско-ранневизейской коре выветривания пород докембрийского фундамента и погребена под мощным (400-800 м) чехлом осадочных образований. Залежи бокситов фиксируются почти на всех железорудных месторождения Белгородского района КМА, однако, промышленное значение они имеют лишь на трех Висловском, Олимпийском, Мелихово-Щебекинском [8], образцы которых послужили объектом данных исследований. Бокситы приурочены к аллитовой зоне латеритного профиля на хлорит-слюдистых, кварцгидрослюдистых, филлитовых и других сланцах. Основными минералами бокситов являются бемит, гиббсит, бертьерин, каолинит, гематит, гетит. Залежи бок- 
ситов пространственно и генетически связаны с толщей богатых железных руд, в которых признаки биогенной жизнедеятельности уже были обнаружены. [9].

Изучались свежие сколы наименее измененные диагенетическими преобразованиями пород, образцы последовательно промывались в спирте и напылялись золотом. Исследования проводились с помощью СЭМ TESCAN VEGA IIXMU в Палеонтологическом институте РАН им. А. А. Борисяка РАН.

При определении ископаемых бактерий основными критериями являются их форма и размеры. Бактерии обычно имеют простую морфологию, это простые шарики, нитки, гантеле- и веретенообразные формы [10].

Вокруг клеток бактерий нередко в виде слизи выделяется внеклеточное вещество - гликокаликс. Также при колонизации организмами твердой поверхности образуются биопленки, которые являются результатом взаимодействия бактерий и продуктов их жизнедеятельности с субстратом. Биопленки представляют собой совокупность микробных клеток, других мельчайших частиц, воды и внеклеточного полимер-

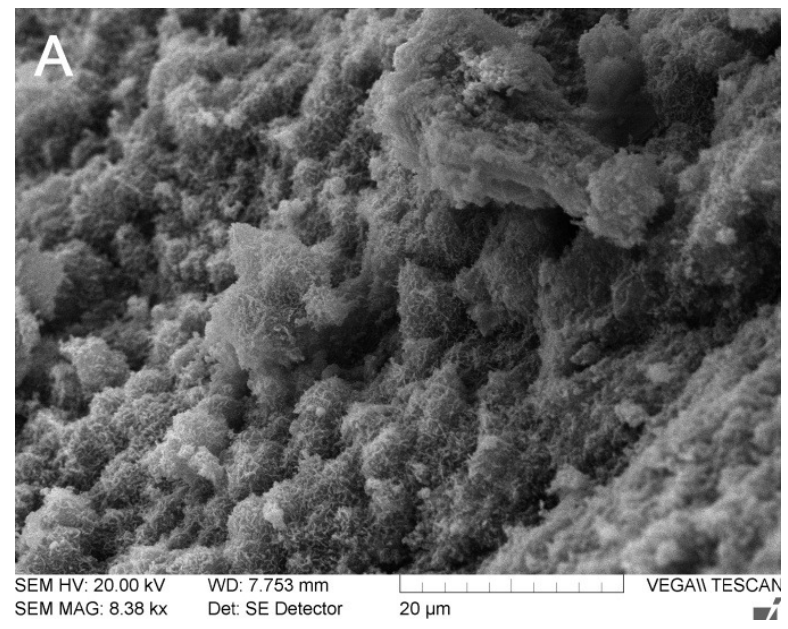

ного органического вещества, которое удерживает клетки вместе и на поверхности [10]. Будучи минерализованными биопленки и гликокаликс нередко сохраняются в ископаемом состоянии.

\section{Характеристика обнаруженных биоморфных структур}

В изучаемых образцах было обнаружено несколько проявлений биоминерализации. Образец каолинитбертьерин-бемитового боксита с Яковлевского месторождения характеризуется ячеистой поверхностью, с многочисленными порами и трещинами. При увеличении поверхность оказалась сложена изгибающимися формами, по структуре напоминающими фоссилизированный гликокаликс, образованный древними микроорганизмами (рис. 1). Подобными структурами покрыта большая часть поверхности породы. Гликокаликс в породе находится на разных стадиях развития минерализации: от едва намечающихся рассеянных микрокристаллов до сплошных друз совершенных кристаллов.

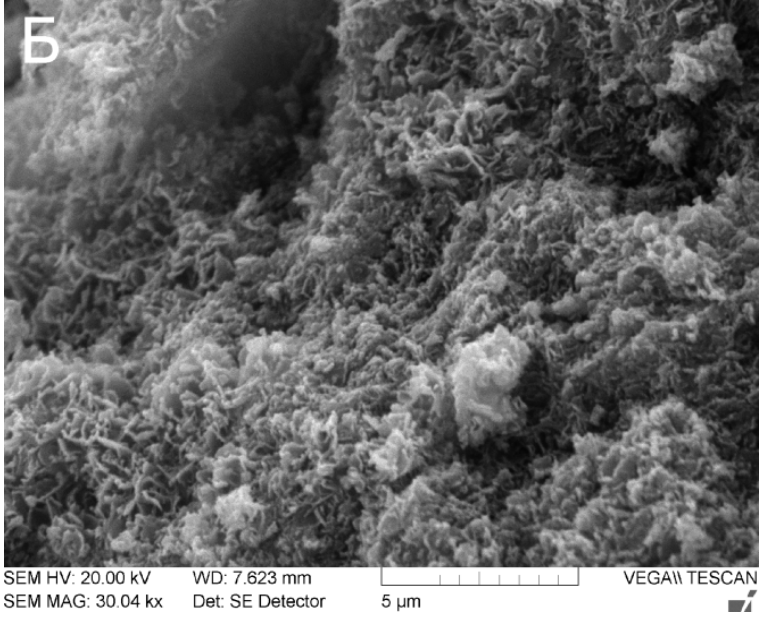

Puc.1. Минерализованный гликокаликс в обр. каолинит-бертьерин-бемитового боксита (Яковлевское месторождение): $A$ - крупный план, 5 - максимальное увеличение.

Помимо гликокаликса, в изученных образцах обнаружены многочисленные биопленки. Поверхность образца каолинит-бемит-бертьеринового боксита месторождения покрыта многочисленными биопленками, местами отслоившимися, в результате дробления породы (рис. 2a). Фрагмент биопленки, показанный на рис. $2 \mathrm{a}$, частично раскристаллизован с бугорчатой поверхностью и закругленными краями. Поверхность образца гиббситового боксита (Ольховатское месторождение) также покрыта биопленками и их фрагментами. В данном случае биопленки плохо раскристаллизованы и представлены сплошной аморфной массой. Также обнаружен расплющенный и свернутый фрагмент минерализованной биопленки размером $30 \mu \mathrm{m} \mathrm{x} 15 \mu$ м, лежащей на поверхности свежего скола породы (рис. 2б).

В образце существенно бемитового боксита присутствуют остатки бактериальных нитей или нитевидных бактерий (рис. 3a). Некоторые объекты по конфи- гурации похожи на гифы грибов, которые неоднократно были обнаружены при изучении других месторождений бокситов [6] (рис. 3б). Таким образом, в данном случае можно предположить симбиоз бактерий с грибами. Поверхности многих образцов покрыты многочисленными переплетающимися фоссилизированными нитчатыми бактериями. Некоторые из них похожи на остатки трихомов цианобактерий и характеризуются большей шириной (до $2 \mu \mathrm{M}$ ), трубчатым обликом, и, вероятно, полым внутренним строением. Они располагаются на удалении друг от друга и пересекаются иногда под прямым углом.

Коккоидные формы распространены ограничены. Обнаружены только в отдельных порах и трещинах образца каолинит-бемит-бертьеринового боксита (рис. 4).

Подобные образования представлены скоплениями мелких (менее $1 \mu \mathrm{M}$ ) округлых и овальных форм, образующих сплошные микробные массы. 

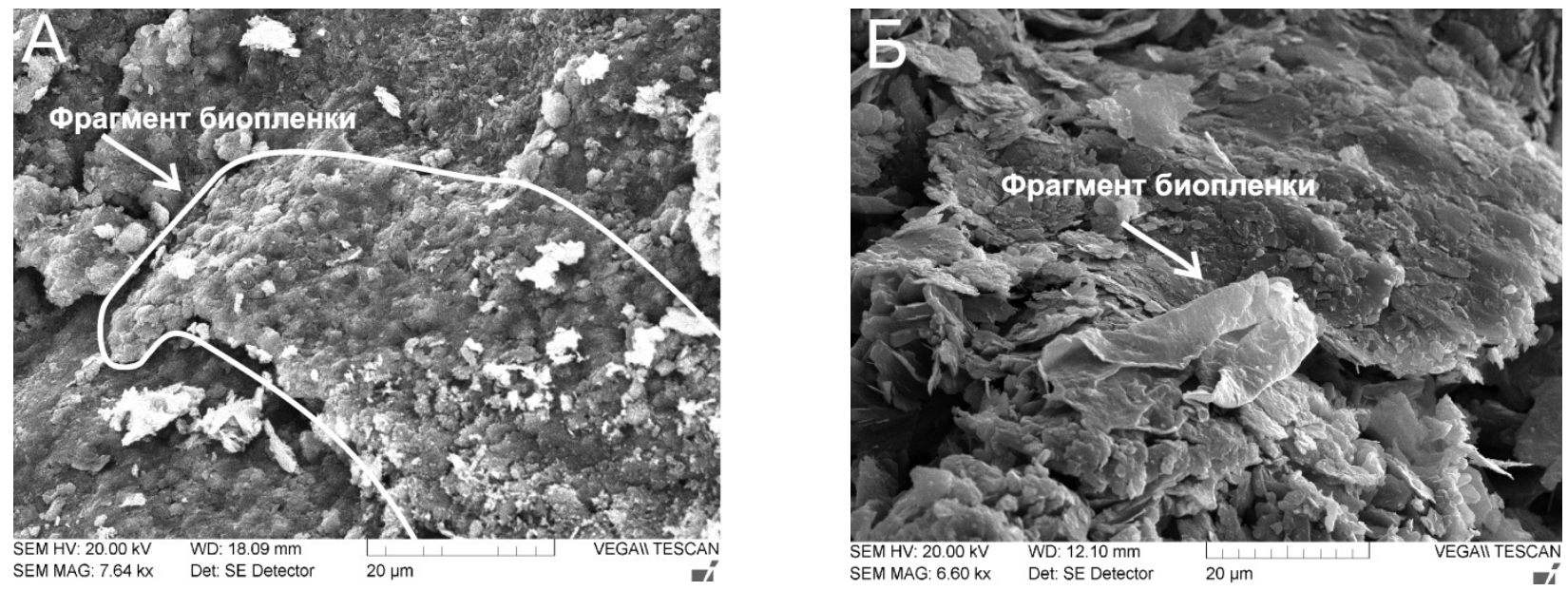

Puc. 2. A- фрагмент биопленки, частично раскристаллизованной с бугорчатой поверхностью и закругленными краями в обр. каолинит-бемит-бертьеринового боксита (Яковлевское месторождение), $Б$ - свернутый фрагмент минерализованной биопленки размером $30 \mu \mathrm{m} \mathrm{x} 15$ м в обр. гиббситового боксита (Ольховатское месторождение).
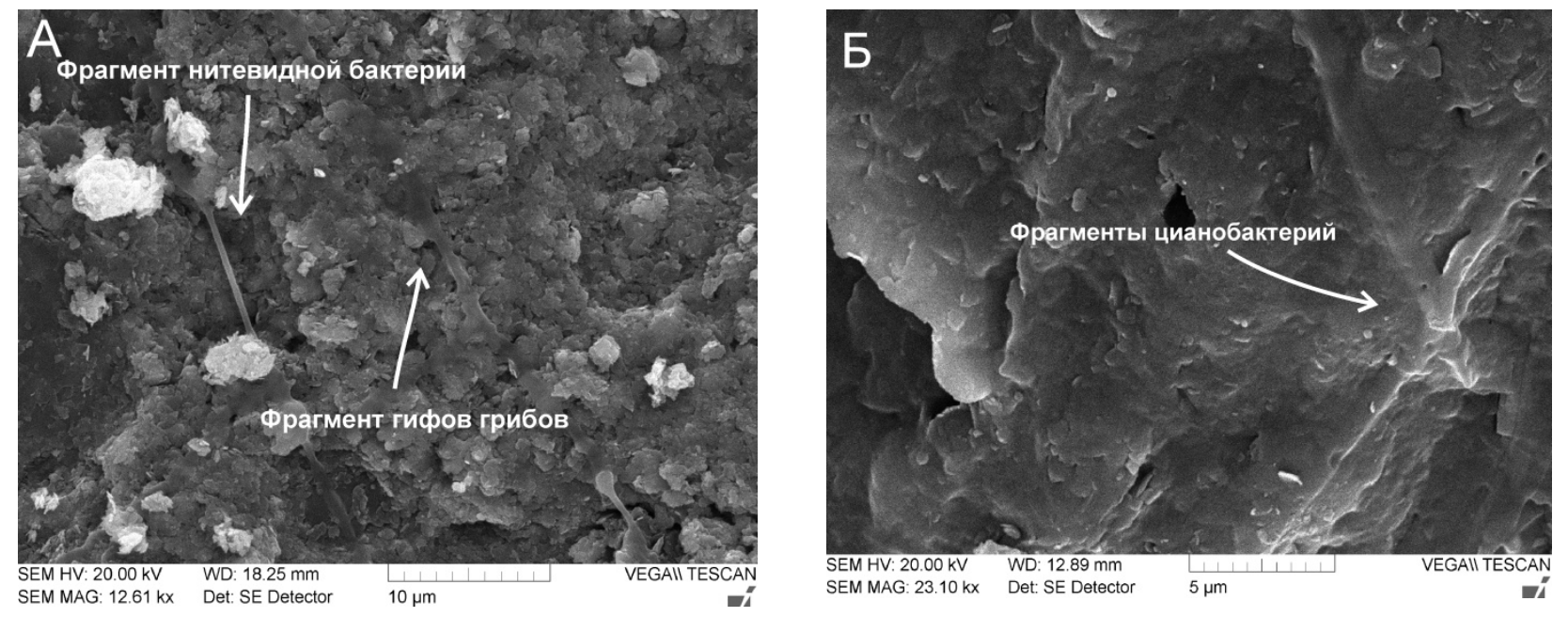

Puc. 3. $A$ - фрагменты нитевидных бактерий и гифов грибов; 5 - фрагменты цианобактерий, обр. существенно бемитового боксита (Мелихово-Щебекинское месторождение).
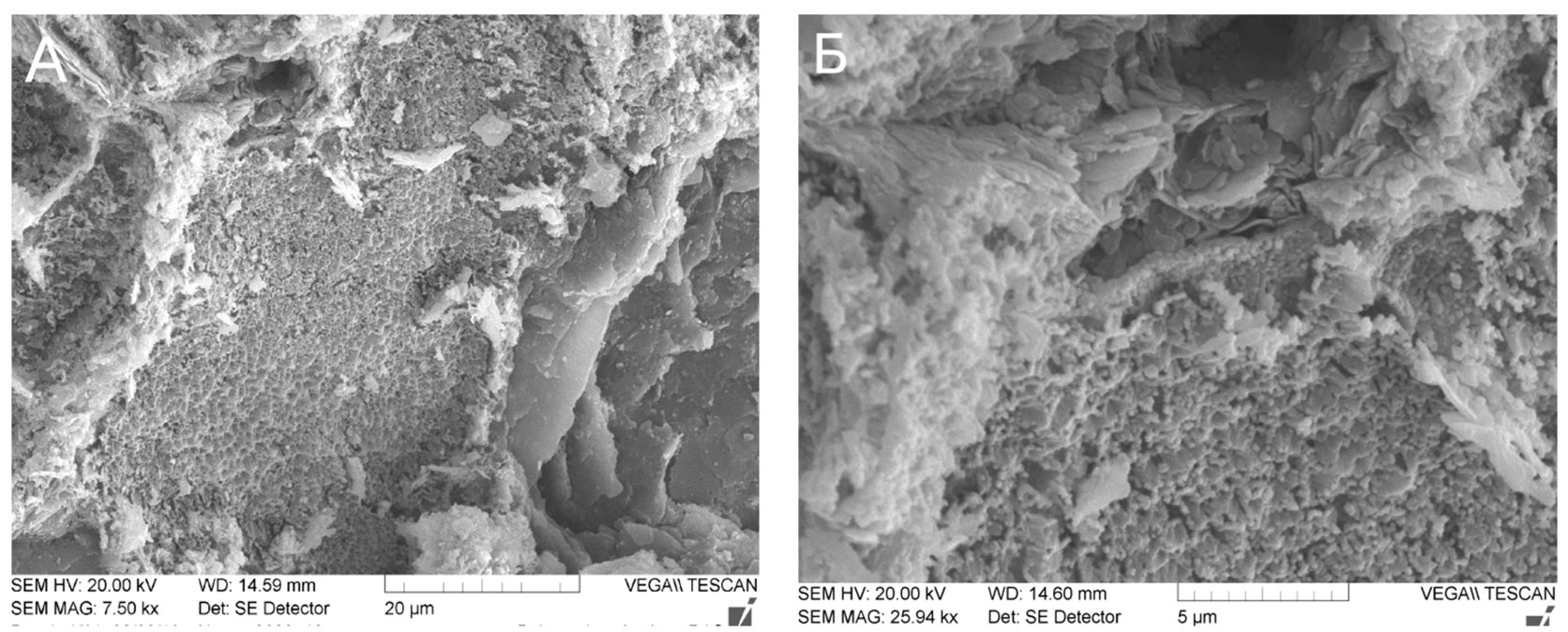

Puc. 4. Коккоидные формы в образце каолинит-бемит-бертьеринового боксита (Яковлевское месторождение): $A-$ крупный план, $Б$ - максимальное увеличение. 


\section{Обсуждение результатов}

В исследуемых образцах латеритных бокситов КМА обнаружены различные по конфигурации и распространению биоморфозы. Количественная их роль в породах изменчива и, по-видимому, зависит как от минерального состава, так и от степени гипергенного преобразования. Максимальное разнообразие наблюдается в породах со значительным присутствием минералов железа и в породах верхней части профиля выветривания.

Образование минералов с участием бактерий происходит двумя способами: биологически вызванной минерализацией (БВМ) и биологически обусловленной минерализацией (БОМ) [11, 12]. При БВМ в бескислородных условиях бактерии взаимодействуют с различными металлами. Метаболические продукты этих взаимодействий являются акцепторами в переносе электронов, очень активны и участвуют в последующем минералообразовании. При БОМ минералы осаждаются на органической матрице или внутри клетки, позволяя организму осуществлять контроль за образованием и ростом минералов, над их составом, размером, габитусом и внутриклеточном положении [11].

Полученные данные позволяют предположить, что на определенной стадии развития латеритного профиля, микроорганизмы начинают играть значительную роль. Вероятно, в дотурнейское время формирования гидрослюдисто-каолинитового профиля на межрудных сланцах уже проявились процессы биогенного преобразования, выраженные в изменении минералов материнских пород. А затем в елховско-бобриковское время (основную стадию латеризации), когда на рассматриваемой территории была суша, в пределах которой образовывались крупные месторождений богатых железных руд на джеспилитах и бокситов на межрудных сланцах $[8,13,14]$, совместно с процессам химического выветривания активизировались и процессы биогенного преобразования, выраженные в преобразовании как минералов материнских пород, так и новообразованных. Помимо разрушающей функции, организмы осуществляли аккумулирующую, накапливая рудное вещество в своих тканях и продуктах жизнедеятельности. При этом не исключается неоднократная колонизация организмами бокситовых залежей и на более поздних этапах.

\section{Выводы}

Результаты проведенных исследований показали, что во всех образцах латеритных бокситов КМА, независимо от состава и положения в профиле выветривания, обнаружены ископаемые остатки микроорганизмов и следы их жизнедеятельности. Распространены такие биоминеральные образования как: гликокаликс, биопленки, покрывающие частично поверхности пород, нитчатые формы различного происхождения, такие как гифы грибов и трихомы цианобактерий. Бактериальные формы находятся на разных стадиях развития и минерализации: от едва намечаю- щихся рассеянных микрокристаллов до сплошных совершенных кристаллов, что может быть связано с положением бокситов в профиле выветривания, и как следствие, с проработанностью гипергенными процессами. Деятельность микроорганизмов ускоряла процессы выветривания, с помощью них происходило разложение алюмосиликатов материнских пород и новообразованных минералов, а также накопление рудного вещества при минерализации тел организмов и продуктов их жизнедеятельности. Наличие биоморфоз в бокситах КМА - повод для постановки вопроса об участии биогенного факторы в их образовании, масштабы которого еще следует обозначить.

Работа выполнена по Программе Президиума РАН № 17 «Эволючия органического мира. Роль и влияние планетарных прочессов» (подпрограмма I «Развитие жизненных и биосферных прочессов»), поддержана грантом РФФИ № 17-04-00324 и Министерством высшего образования и науки РФ.

\section{ЛИТЕРАТУРА}

1. Берг, Л. С. О происхождении уральских палеозойских бокситов / Л. С. Берг // Изв. АН. СССР, сер.геол. 1948. №2. - C. 127- 141 .

2. Вологдин, А. Г. Геологическая деятельность микроорганизмов/ А. Г. Вологдин // Изв. АН. СССР, сер.геол 1947. №3. - C. 19-38

3. Некоторые результаты изучения латеритных продуктов выветривания под сканирующим микроскопом / А. Д. Слукин [и др.] // Кора выветривания. Вып. 19. М., Наука. 1986. - C. $86-91$.

4. Роль микроорганизмов в формировании латеритных кор выветривания и бокситов / А. П. Никитина [и др.] // Кора выветривания. Вып. 20. М., Наука. - 1991. - С. 179-191

5. Аристовская, Т. В. Биогенный механизм формирования бокситов / Т. В. Аристовская, Л. В. Зыкина // Роль биохимических исследований в расширении минерально-сырьевой базы. Л., Наука. - 1986. - С. 95-103

6. Биоморфные структуры в бокситах: (по результатам электронно-микроскопического изучения) / Э. Л. Школьник [и др.]; науч. ред.: В. Т. Фролов. - М. : Эслан, 2004. - 112 с.

7. Бактериальная палеонтология как ключ к пониманию генезиса латеритный бокситов / А. Д. Слукин [и др.] // Тезисы докладов 14-я международной научно-практической конференции «Новые идеи в науках о Земле». Т.1. Развитие новых идей и тенденций в науках о Земле - геологии, геотектонике, геодинамике, региональное геологии, палеонтологии. г. Москва. 2-5 апреля 2019 г. - С. 165-169.

8. Сиротин, В. И. Бокситы КМА / В. И. Сиротин, Е. Е. Белявцева. - Тр. науч.-исслед. ин-та геологии Воронеж. унта. - Вып. 93. - Воронеж: Изд-во Воронеж. ун-та, 2016. $104 \mathrm{c}$.

9. Меркушова, М. Ю. Биоморфные структуры в богатых железных рудах КМА (по результатам электронномикроскопического исследования) / М. Ю. Меркушова, Е. А. Жегалло // Вестник Воронеж. гос. ун-та. Сер. Геология. 2016. - № 2. - С. 150-154.

10. Бактериальная палеонтология / С. С. Абызов [и др.]. Ред. А. Ю. Розанов. - М. : ПИН РАН, 2002. - 188 с. :

11. Frankel, R. B. Biologically induced mineralization by bacteria / R. B. Frankel, D. A. Bazylinski // Rev. Mineral. Geochem. - 2003. - V. 54. - P. 95-114. 
12. Биоминералы латеритных бокситов - новые данные по результатам электронно-микроскопического изучения / А.Д. Слукин [и др.] // Новые данные о минералах. - 2016. - вып. $51-$ C. $52-61$

13. Савко, А. Д. Фанерозойские коры выветривания и связанные с ними отложения Воронежской антеклизы, их не-

ФГБОУ ВО «Воронежский государственный университет»

Овчинникова Марина Юрьевна, аспирант кафедры исторической геологии и палеонтологии

E-mail:marina.merkushova@mail.ru

Тел.: +7 (473)220 8634

ФГБУН Палеонтологический институт имени А. А. Борисяка РАН, г. Москва

Жегалло Елена Александровна, кандидат геологоминералогических наук, старший научный сотрудник

E-mail:ezheg@paleo.ru

Тел.:+7 (495)3399144 металлические полезные ископаемые : дис. ... д-ра геол.минерал. наук. - Воронеж, 1984. - 551 с.

14. Никулин, И. И. Железорудные коры выветривания Белгородского района Курской Магнитной Аномалии / И. И. Никулин, А. Д. Савко. - Тр. науч.-исслед. ин-та геологии Воронеж. ун-та. - Вып. 85. - Воронеж: Изд-во Воронеж. унта, 2015. -102 c.

\section{Voronezh State University}

Ovchinnikova M. Yu., Postgraduate student of the Historical Geology and Paleontology Department

E-mail:marina.merkushova@mail.ru

Tel.: +7 (473)2208634

Borissiak Paleontological Institute of the Russian Academy of Sciences, Moscow

Zhegallo E. A., Candidate of Geological and Mineralogical Sciences, senior researcher

E-mail:ezheg@paleo.ru

Tel.:+7 (495)3399144 